\title{
Senyawa Fenolik dari Daun Tanaman Kalanchoe prolifera (Crassulaceae)
}

\section{Phenolic Compounds from The Leaf of Kalanchoe prolifera (Crassulaceae) Plant}

\author{
Yenny Febriani Yun ${ }^{1,}$, Lilis Siti Aisyah ${ }^{1,2}$, Tri Reksa Saputra ${ }^{2}$, Arif Rahman Hakim², \\ Sari Purbaya $^{1}$, Tati Herlina', Euis Julaeha ${ }^{2}$, Achmad Zainuddin', Unang Supratman' \\ ${ }^{1}$ Jurusan Kimia, FMIPA, Universitas Jenderal Achmad Yani, Cimahi 40528 \\ ${ }^{2}$ Kelompok Kimia Bahan Alam, Jurusan Kimia, Fakultas Matematika dan Ilmu Pengetahuan Alam, Universitas \\ Padjadjaran, Bandung-Sumedang Km 21, Jatinangor, Sumedang 45363
}

Email: yennyfy@gmail.com ; u_supratman@unpad.ac.id

Received: Maret 2017; Revised: April 2017; Accepted: Mei 2017; Available Online: Mei 2017

\begin{abstract}
Abstrak
Senyawa fenolik yang terdiri dari kaemferol (1), kuersetin (2), dan metil kafeat (3) telah diisolasi dari ekstrak etil asetat Kalanchoe prolifera (Crassulaceae). Struktur kimia dari senyawa yang diisolasi 1-3 dielusidasi menggunakan spektroskopi (UV, IR, NMR), dan dibandingkan melalui literatur yang telah dipublikasikan.
\end{abstract}

Kata Kunci: Crassulaceae, Kalanchoe prolifera, senyawa fenolik

\begin{abstract}
Phenolic compounds such as kaempferol (1), quercetin (2), and methyl caffeate (3) have been isolated from the ethyl acetate extract of Kalanchoe prolifera (Crassulaceae). The chemical structure of isolated compounds 1-3 were elucidated on the basis of spectroscopic evidence (UV, IR, NMR) and comparison with those compound previouly reported.
\end{abstract}

Keywords: Crassulaceae, Kalanchoe prolifera, phenolic compounds.

DOI: http://dx.doi.org/10.15408/jkv.v0i0.5037

\section{PENDAHULUAN}

Tumbuhan merupakan sumber utama senyawa metabolit sekunder, dan bersifat khas pada spesies tertentu, serta tidak berperan dalam proses metabolisme primer tanaman, melainkan berperan penting pada kelangsungan hidup tumbuhan sebagai pertahanan diri dari pengaruh lingkungan sekitarnya (Kennedy dan Wightman, 2011; Edriss et al., 2012).

Indonesia memiliki keanekaragaman hayati terbesar di dunia dengan lebih dari 38.000 spesies tumbuhan, memiliki potensi yang besar untuk dijadikan bahan obat atau kegunaan lainnya. Sebagai upaya pemanfaatan dan pendataan potensi sumber daya hayati khususnya tumbuhan, perlu dilakukan pencarian bahan-bahan kimia yang bermanfaat sebagai bahan obat secara sistematis (Harvey, 2008; Kementrian Kehutanan RI, 2010). Salah satu tumbuhan yang terdapat di Indonesia adalah tumbuhan Kalanchoe.

Tumbuhan Kalanchoe mempunyai 133 spesies, merupakan genus terbesar dari famili Crassulaceae dan berasal dari Madagaskar (Gao et al., 2011). Tumbuhan ini tumbuh baik dan tersebar luas di Indonesia karena kemampuannya untuk beradaptasi di lahan kering, sehingga merupakan salah satu kekayaan keanekaragaman tumbuhan Indonesia. 
Tumbuhan Kalanchoe kaya akan kandungan flavonoid, steroid, alkaloid, triterpen, glikosida, lipid, antosianin, kumarin, bufadienolida, fenantren, dan asam organik (Supratman et al., 2000; Costa et al., 2008; Gao et al., 2011; Biswas et al., 2011; Milad et al., 2014). Penelitian tentang Kalanchoe dipelopori oleh Gaind dan Gupta pada tahun 1971 dan 1973 (Gaind dan Gupta, 1971), dengan mengeksplorasi kandungan senyawa flavonoid dari Kalanchoe pinnata. Liu et al. (1989) melaporkan adanya 7-hidroksikumarin dari $K$. gracillis, dan 59 senyawa flavonoid dari sembilan spesies tumbuhan Kalanchoe berhasil diisolasi (Liu et al., 1989; Costa et al., 2008). Bufadienolida merupakan metabolit sekunder yang telah diisolasi dari enam spesies genus Kalanchoe (Anderson et al., 1983; Wagner et al., 1985; Supratman et al., 2000; Yamagishi et al., 1989; Wu et al., 2006; Kuo et al., 2008). Metabolit sekunder lainnya dilaporkan sebagai asam fenolat dan megastigman dari ekstrak metanol $K$. hybrida dan ekstrak etil asetat $K$. marmorata, sedangkan sterol, triterpen, dan fenantren diisolasi dari daun segar $K$. pinnata dan $K$. thrysiflora (Milad et al., 2014). Milad et al. (2014) melaporkan bahwa asam-asam lemak telah ditemukan dalam $K$. pinnata dan dua spesies Kalanchoe lainnya mengandung garam-garam organik (Milad et al., 2014).

Mengingat tumbuhan Kalanchoe tersebar luas sampai ke Indonesia dan baru 17 spesies yang telah dikaji (lima diantaranya tumbuh di Indonesia) dari 133 spesies yang tersedia di dunia, serta potensi kandungan metabolit sekunder tumbuhan Kalanchoe, maka menarik untuk dilakukan penelitian dan pengkajian potensi kandungan metabolit sekunder tumbuhan Kalanchoe dalam upaya pencarian senyawa-senyawa metabolit sekunder dari tumbuhan Kalanchoe yang tumbuh di Indonesia. Pada penelitian ini dilakukan eksplorasi kandungan metabolit sekunder dari spesies Kalanchoe prolifera, mengingat informasi mengenai kandungan metabolit sekunder dari spesies ini belum banyak dipublikasikan. Berdasarkan Costa et al., 2008 baru ditemukan satu senyawa flavonoid yaitu kuersetin 3-O- $\beta$-Lglukopiranosil $(1 \rightarrow 2)-\beta$-D-silopiranosida. Oleh karena itu menjadi suatu peluang penelitian untuk mengeksplorasi senyawa metabolit sekunder lainnya dari $K$. prolifera.

\section{METODE PENELITIAN}

\section{Alat dan Bahan}

Spektra Ultra-Violet diukur dalam methanol pada spektrofotometer jasco UV1575. Spektra IR diukur pada Perkin Elmer spectrum-100 FT-IR dalam KBr. Spektra NMR diukur dengan JEOL JNM A-500 spectrometer menggunakan tetra methyl silane (TMS) sebagai standard. Pemisahan dilakukan dengan berbagai teknik Kromatografi dengan silika gel 60 (Merck). Plat TLC silika gel $\mathrm{GF}_{254}$ (Merck, $0.25 \mathrm{~mm}$ ) dan dideteksi dengan $10 \%$ $\mathrm{H}_{2} \mathrm{SO}_{4}$ dalam etanol,dilanjutkan dengan pemanasan.

Daun segar $K$. prolifera dikumpulkan dari Lembang, Bandung Barat, Indonesia pada Mei, 2016. Tumbuhan diidentifikasi di Bogoriense Herbarium, Bogor, Indonesia dan nomor specimen (No. B0-129212) disimpan sebagai herbarium.

\section{Ekstraksi dan Isolasi}

Masing-masing daun segar $K$. prolifera $(9.8 \mathrm{~kg})$ dibersihkan, dipotong kecil, lalu dihaluskan. Potongan halus daun yang diperoleh, dimaserasi dengan metanol secara tuntas pada suhu kamar, dan dilanjutkan dengan penguapan menggunakan rotary evaporator (suhu di bawah $40{ }^{\circ} \mathrm{C}$ ) sehingga diperoleh maserat pekat metanol. Maserat pekat metanol yang diperoleh diekstraksi dengan air distilasi, kemudian dipartisi dengan pelarut $n$-heksan, sehingga didapatkan fraksi $n$ heksan dan lapisan air. Fraksi n-heksan dipisahkan dan dipekatkan dengan rotary evaporator, menghasilkan ekstrak pekat $n$ heksan $K$. prolifera $(24.8 \mathrm{~g})$. Lapisan air yang diperoleh kemudian dipartisi dengan metilen klorida, sehingga didapatkan fraksi metilen klorida dan lapisan air. Fraksi metilen klorida selanjutnya dilarutkan di dalam air dan dipartisi dengan etil asetat. Fraksi etil asetat dipekatkan dengan rotary evaporator, menghasilkan ekstrak pekat etil asetat $K$. prolifera $(44.4 \mathrm{~g})$.

Fraksi $n$-heksan (24.8 g) dipisahkan dengan kromatografi cair vakum pada fasa diam silika gel $\mathrm{G}_{60}$ dengan fasa gerak $n$ heksan-etil asetat-metanol $10 \%(\mathrm{v} / \mathrm{v})$ secara gradien, sehingga diperoleh 28 fraksi dan dilakukan penggabungan sehingga diperoleh sepuluh fraksi gabungan (1-10). Pemisahan dilanjutkan pada fraksi delapan $(271.0 \mathrm{mg})$ dengan kromatografi kolom pada fasa diam 
silika gel (70-230 mesh) dengan fasa gerak etil asetat, sehingga diperoleh 123 fraksi. Berdasarkan analisis KLT, maka fraksi tersebut digabung dan didapatkan tujuh fraksi (8.1-8.7). Fraksi 8.5 (198 mg) dipisahkan dengan kromatografi kolom pada fasa diam silika gel (70-230 mesh) dengan fasa gerak kloroform:metanol $(9: 1)$, sehingga didapatkan 78 fraksi, dilanjutkan dengan penggabungan, sehingga didapatkan empat fraksi utama (8.5.1-8.5.4). Berdasarkan analisis KLT fraksi 8.5.3 (147 $\mathrm{mg})$ dipisahkan dengan kromatografi lapis tipis preparatif pada fasa diam silika gel $\mathrm{GF}_{254}$ dan fasa gerak kloroform : metanol (9:1) sehingga didapatkan senyawa 3 (12.8 $\mathrm{mg})$, berupa padatan amorf putih.

Fraksi etil asetat (44.4 g) dipisahkan dengan kromatografi cair vakum pada fasa diam silika gel $\mathrm{G}_{60}$ dan fasa gerak $n$-heksan-etil asetat-metanol $10 \% \quad(\mathrm{v} / \mathrm{v})$ secara gradien, sehingga diperoleh 28 fraksi. Berdasarkan analisis kromatografi lapis tipis dilakukan penggabungan sehingga diperoleh sepuluh fraksi gabungan (1-10). Pada fraksi 6 dan 8 dilakukan pemisahan lebih lanjut.

Fraksi delapan $(147 \mathrm{mg})$ dipisahkan lebih lanjut dengan kromatografi kolom pada fasa diam silika gel (70-230 mesh) dengan fasa gerak $n$-heksan-etil asetat-metanol $10 \% \mathrm{v} / \mathrm{v}$ secara gradien, sehingga diperoleh 22 fraksi. Berdasarkan analisis KLT, maka fraksi tersebut digabung dan didapatkan sembilan fraksi (8.1-8.9). Fraksi $8.8 \quad(98.0 \quad \mathrm{mg})$ dipisahkan menggunakan kromatografi lapis tipis preparatif pada fasa diam silika gel $\mathrm{GF}_{254}$ dan fasa gerak kloroform : aseton (7:3), sehingga didapatkan dua isolat. Berdasarkan kesamaan pola KLT, visualisasi dan penampilan fisik dari isolat, maka didapatkan senyawa $1(11.2 \mathrm{mg})$ dan senyawa $2(5.4 \mathrm{mg})$ berupa padatan kuning.

\section{Penentuan Struktur Isolat}

Struktur kimia isolat murni ditetapkan dengan berdasarkan data spektroskopi meliputi: ultra violet, inframerah, resonansi magnet inti proton $\left({ }^{1} \mathrm{H}-\mathrm{NMR}\right)$, karbon $\left({ }^{13} \mathrm{C}\right.$ NMR), Distortionless Enhancement by Polarization Transfer (DEPT), dan massa, serta perbandingan data spektra yang diperoleh dari literatur.

\section{HASIL DAN PEMBAHASAN}

\section{Senyawa 1}

Senyawa 1 diperoleh sebagai padatan kuning, titik leleh $277-279{ }^{\circ} \mathrm{C}$, spektrum UV (metanol) $\lambda_{\text {maks }} \mathrm{nm}: 257,377$; spektrum UV (metanol+ $\left.\mathrm{AlCl}_{3}\right) \lambda_{\text {maks }}$ nm: 268, 349; spektrum IR (KBr) $v_{\text {maks }} \mathrm{cm}^{-1}: 3427$ dan 1640; spektrum ${ }^{1} \mathrm{H}-\mathrm{NMR}$ (aseton- $\left.d_{6}, 500 \mathrm{MHz}\right) \delta_{\mathrm{H}}(\mathrm{ppm})$ dan spektrum ${ }^{13} \mathrm{C}-\mathrm{NMR}$ (aseton- $d_{6}, 125 \mathrm{MHz}$ ) $\delta_{\mathrm{C}}(\mathrm{ppm})$ : (Tabel 1).

\section{Struktur Kimia Senyawa 1}

Senyawa 1 diperoleh sebagai padatan kuning, titik leleh 277-279 ${ }^{\circ} \mathrm{C} \quad\left(276{ }^{\circ} \mathrm{C}\right.$ Chaturvedula dan Prakash, 2011). Kromatogram lapis tipis senyawa 1 memperlihatkan pendaran di bawah sinar UV pada $\lambda_{\text {maks }} 254$ dan $365 \mathrm{~nm}$, menunjukkan adanya sistem ikatan rangkap terkonyugasi. Spektrum UV senyawa 1, menunjukkan serapan pada $\lambda_{\text {maks }} 377(\varepsilon 6.200)$ dan $257 \mathrm{~nm}(\varepsilon$ 7.200). Pada spektrum ${ }^{1} \mathrm{H}-\mathrm{NMR}$ tampak adanya sinyal singlet pada $\delta_{\mathrm{H}} 12,11 \mathrm{ppm}$ yang berarti terdapat gugus $-\mathrm{OH}$ di C-5. Selanjutnya sepasang sinyal proton aromatik pada $\delta_{\mathrm{H}} 6.27$ dan $6.54 \mathrm{ppm}(J=1.9 \mathrm{~Hz})$ merupakan sinyal proton dari $\mathrm{C}-6$ dan $\mathrm{C}-8$,sehingga di C-7 terdapat gugus $-\mathrm{OH}$. Dua sinyal proton aromatik $2 \mathrm{H}$ pada $\delta_{\mathrm{H}} 7.03$ dan $8.17 \mathrm{ppm}$ berkopling orto $(J=9.0 \mathrm{~Hz})$ menunjukkan di cincin B terdapat gugus -OH pada C-4. Dengan demikian dapat disimpulkan bahwa senyawa 1 adalah 5,7,4'-trihidroksiflavonol atau kaempferol. Perbandingan data NMR senyawa 1 dengan kaempferol (Chaturvedula dan Prakash, 2001), menunjukkan kesesuaian yang sangat tinggi, dengan demikian senyawa 1 diidentifikasikan sebagai kaempferol seperti ditunjukkan pada gambar 1 dan tabel 1 .<smiles>O=c1c(O)c(-c2ccc(O)cc2)oc2cc(O)cc(O)c12</smiles>

Gambar 1. Kaempferol (1) 
Tabel 1. Data NMR senyawa 1 dan kaempferol

\begin{tabular}{|c|c|c|c|c|}
\hline \multirow{3}{*}{$\begin{array}{l}\text { Posisi } \\
\text { Atom C }\end{array}$} & \multicolumn{2}{|l|}{ Senyawa $1 *$} & \multicolumn{2}{|l|}{ Kaempferol $* *$} \\
\hline & ${ }^{1}$ H-NMR & ${ }^{13} \mathrm{C}-\mathrm{NMR}$ & ${ }^{1} \mathrm{H}-\mathrm{NMR}$ & ${ }^{13} \mathrm{C}-\mathrm{NMR}$ \\
\hline & $\begin{array}{l}\delta_{\mathrm{H}}(\mathrm{ppm}) \\
(\Sigma \mathrm{H} ; \text { mult.; } J=\mathrm{Hz})\end{array}$ & $\delta_{\mathrm{C}}(\mathbf{p p m})$ & $\begin{array}{l}\delta_{\mathrm{H}}(\mathbf{p p m}) \\
(\Sigma \mathrm{H} ; \text { mult.; } J=\mathbf{H z})\end{array}$ & $\delta_{\mathrm{C}}(\mathbf{p p m})$ \\
\hline 1 & - & - & - & - \\
\hline 2 & - & 157.8 & - & 157.8 \\
\hline 3 & - & 136.7 & - & 136.0 \\
\hline 4 & - & 176.6 & - & 176.2 \\
\hline 5 & $12.11(1 \mathrm{H}, s)$ & 162.3 & - & 162.6 \\
\hline 6 & $6.27(1 \mathrm{H}, d, 1.9)$ & 99.2 & $6.28(1 \mathrm{H}, d, 1.8)$ & 99.9 \\
\hline 7 & - & 165.1 & - & 165.6 \\
\hline 8 & $6.54(1 \mathrm{H}, d, 1.9)$ & 94.5 & $6.74(1 \mathrm{H}, d, 1.8)$ & 94.5 \\
\hline 9 & - & 157.8 & - & 157.6 \\
\hline 10 & - & 104.1 & - & 105.5 \\
\hline $1^{\prime}$ & - & 123.3 & - & 121.7 \\
\hline $2^{\prime}$ & $8.17(1 \mathrm{H}, d, 9.1)$ & 130.5 & 7.83( $1 \mathrm{H}, d, 8.9)$ & 131.5 \\
\hline $3^{\prime}$ & $7.03(1 \mathrm{H}, d, 9.0)$ & 116.4 & $7.02(1 \mathrm{H}, d, 9.0)$ & 116.4 \\
\hline $4^{\prime}$ & - & 162.3 & - & 161.8 \\
\hline $5^{\prime}$ & $7.03(1 \mathrm{H}, d, 9.0)$ & 116.4 & $7.02(1 \mathrm{H}, d, 9.0)$ & 116.4 \\
\hline $6^{\prime}$ & $8.17(1 \mathrm{H}, d, 9.1)$ & 130.5 & $7.83(1 \mathrm{H}, d, 8.9)$ & 131.6 \\
\hline
\end{tabular}

\section{Senyawa 2}

Senyawa 2 diperoleh sebagai padatan kuning; titik leleh $315-317{ }^{\circ} \mathrm{C}$, spektrum UV (metanol) $\lambda_{\text {maks }} \mathrm{nm}: 255$ ( $\varepsilon$ 6.200), 370 ( $\varepsilon$ 7.200); spektrum UV (metanol+AlCl ${ }_{3}$ ) $\lambda_{\text {maks }}$ nm: 268, 340; spektrum IR (KBr) $v_{\text {maks }} \mathrm{cm}^{-1}$ : 3413 dan 1608; spektrum ${ }^{1} \mathrm{H}-\mathrm{NMR}$ (aseton- $d_{6}$, $500 \mathrm{MHz}) \delta_{\mathrm{H}}(\mathrm{ppm})$ dan spektrum ${ }^{13} \mathrm{C}-\mathrm{NMR}$ (aseton- $\left.d_{6}, 125 \mathrm{MHz}\right) \delta_{\mathrm{C}}(\mathrm{ppm})$ : (tabel 2).

\section{Struktur Kimia Senyawa 2}

Senyawa 2 diperoleh sebagai padatan kuning, titik leleh $315-317{ }^{\circ} \mathrm{C}\left(316{ }^{\circ} \mathrm{C}\right.$ Awaad et al., 2008) . Serapan-serapan UV dan IR menunjukkan karakteristik yang mirip dengan senyawa 1, sehingga diusulkan senyawa 2 juga merupakan flavonoid dengan kerangka flavonol (Markam, 1988). Struktur flavonol pada senyawa 2 juga ditunjukkan oleh adanya dua sinyal karbon dari ${ }^{13} \mathrm{C}-\mathrm{NMR}$ pada $\delta \mathrm{c} 176.5$ dan 136.7 ppm (Son dan Phuc, 2013; Markam, 1988) seperti yang terlihat pada Gambar 2.

Spektrum ${ }^{1} \mathrm{H}-\mathrm{NMR}$ senyawa 2 memperlihatkan sepasang sinyal proton aromatik pada $\delta_{\mathrm{H}} 6.23$ dan $6.49 \mathrm{ppm}$ berkopling meta $(J=1.9 \mathrm{~Hz})$ merupakan sinyal proton dari C-6 dan C-8, sehingga di C-7 terdapat gugus $-\mathrm{OH}$. Tiga sinyal proton aromatik lainnya muncul sebagai sistem $\mathrm{ABX}$ yang beresonansi pada $\delta_{\mathrm{H}} 6.97$ dan $7.79 \mathrm{ppm}$ berkopling meta $(J=1.9 \mathrm{~Hz})$, sedangkan pada $\delta_{\mathrm{H}} 6.97$ dan $7.79 \mathrm{ppm}$ berkopling orto $(J=8,4$ $\mathrm{Hz}$ ) mengindikasikan di C-2' dan C-4' terdapat gugus $-\mathrm{OH}$.

Perbandingan data NMR senyawa 2 dengan kuersetin (Awaad et al., 2008), menunjukkan kesesuaian yang sangat tinggi, dengan demikian senyawa 2 diidentifikasikan sebaga kuersetin seperti ditunjukkan pada gambar 2 dan tabel 2.<smiles>O=c1c(O)c(-c2ccc(O)c(O)c2)oc2cc(O)cc(O)c12</smiles>

Gambar 2. Kuersetin (2) 
Tabel 2. Data NMR senyawa 2 dan kuersetin

\begin{tabular}{|c|c|c|c|c|}
\hline \multirow[b]{2}{*}{$\begin{array}{l}\text { Posisi } \\
\text { Atom C }\end{array}$} & \multicolumn{2}{|l|}{ Senyawa $2 *$} & \multicolumn{2}{|l|}{ Kuersetin** } \\
\hline & $\begin{array}{l}{ }^{1} \mathrm{H}-\mathrm{NMR} \\
\delta_{\mathrm{H}}(\mathbf{p p m}) \\
(\Sigma \mathrm{H} ; \text { mult.; } J=\mathrm{Hz})\end{array}$ & $\begin{array}{l}{ }^{13} \mathrm{C}-\mathrm{NMR} \\
\delta_{\mathrm{C}}(\mathrm{ppm})\end{array}$ & $\begin{array}{l}{ }^{1} \mathrm{H}-\mathrm{NMR} \\
\delta_{\mathrm{H}}(\mathrm{ppm}) \\
(\Sigma \mathrm{H} ; \text { mult.; } J=\mathrm{Hz})\end{array}$ & $\begin{array}{l}{ }^{13} \mathrm{C}-\mathrm{NMR} \\
\delta_{\mathrm{C}}(\mathrm{ppm})\end{array}$ \\
\hline 1 & - & - & - & - \\
\hline 2 & - & 157.8 & - & 156.6 \\
\hline 3 & - & 136.7 & - & 136.2 \\
\hline 4 & - & 176.5 & - & 176.3 \\
\hline 5 & - & 162.1 & - & 161.2 \\
\hline 6 & $6.23(1 \mathrm{H}, d, 1.9)$ & 99.1 & $6.37(1 \mathrm{H}, d, 2.5)$ & 98.8 \\
\hline 7 & & 164.9 & - & 164.5 \\
\hline 8 & $6.49(1 \mathrm{H}, d, 1.9)$ & 94.3 & $6.14(1 \mathrm{H}, d, 2.5)$ & 93.7 \\
\hline 9 & - & 148.8 & - & 148.2 \\
\hline 10 & - & 104.1 & - & 103.4 \\
\hline $1^{\prime}$ & - & 121.4 & - & 120.4 \\
\hline $2^{\prime}$ & $7.79(1 \mathrm{H}, d, 1.9)$ & 115.7 & $7.64(1 \mathrm{H}, d, 2.5)$ & 116.1 \\
\hline $3^{\prime}$ & - & 145.8 & - & 145.5 \\
\hline $4^{\prime}$ & - & 146.9 & - & 147.2 \\
\hline $5^{\prime}$ & $6.97(1 \mathrm{H}, d, 8.4)$ & 116.2 & $6.85(1 \mathrm{H}, d, 8.5)$ & 115.5 \\
\hline 6 & $7.79(1 \mathrm{H}, d d, 1.9 ; 8.4)$ & 123.7 & $7.49(1 \mathrm{H}, d d, 2.5 ; 8.5)$ & 122.4 \\
\hline
\end{tabular}

* Pengukuran dilakukan dengan aseton- $d_{6}$ pada $500 \mathrm{MHz}$ untuk ${ }^{1} \mathrm{H}$ dan $125 \mathrm{MHz}$ untuk ${ }^{13} \mathrm{C}-\mathrm{NMR}$ ** Pengukuran dilakukan dalam DMSO- $d_{6}$ pada $600 \mathrm{MHz}$ untuk ${ }^{1} \mathrm{H}$ dan $150 \mathrm{MHz}$ untuk ${ }^{13} \mathrm{C}_{-} \mathrm{NMR}^{(\text {Awaad et al., 2008) }}$

\section{Senyawa 3}

Senyawa 3 diperoleh sebagai padatan putih, titik leleh $164-166{ }^{\circ} \mathrm{C}$; spektrum UV (metanol) $\lambda_{\text {maks }} \mathrm{nm}$ : 244,345 ; spektrum IR (KBr) $v_{\text {maks }} \mathrm{cm}^{-1} 3441,1701,1343$, dan 1037. Spektrum ${ }^{1} \mathrm{H}-\mathrm{NMR}$ (aseton- $\left.d_{6}, 500 \mathrm{MHz}\right) \delta_{\mathrm{H}}$ (ppm) dan spektrum ${ }^{13} \mathrm{C}$-NMR (aseton- $d_{6,125}$ MHz) $\delta_{\mathrm{C}}$ (ppm): (tabel 3).

\section{Struktur Kimia Senyawa 3}

Senyawa 3 diperoleh sebagai padatan putih Kromatogram lapis tipis senyawa 3 memperlihatkan pendaran dibawah sinar UV pada $\lambda_{\text {maks }} 254 \mathrm{~nm}$ dan $365 \mathrm{~nm}$, menunjukkan sistem ikatan rangkap terkonyugasi sedangkan spektrum IR memperlihatkan adanya serapan yang berasal dari gugus hidroksil ( $v_{\text {maks }} 3441$ $\left.\mathrm{cm}^{-1}\right)$, gugus karbonil $\left(v_{\text {maks }} 1701 \mathrm{~cm}^{-1}\right)$, ikatan rangkap dua dari cincin aromatik $\left(v_{\text {maks }} 1342\right.$ $\left.\mathrm{cm}^{-1}\right)$, dan ikatan C-O dari ester $\left(v_{\text {maks }} 1037 \mathrm{~cm}^{-}\right.$ ${ }^{1}$ ), diduga senyawa 3 merupakan senyawa turunan asam fenolat.

Spektrum ${ }^{13} \mathrm{C}$-NMR dan HMQC senyawa 3 memiliki sepuluh sinyal karbon, sebagai satu ester pada $\delta c 167.8 \mathrm{ppm}$ dan satu sinyal karbon metil teroksigenasi pada $\delta$ c 51.5 ppm, dua sinyal karbon metin $s p^{2}$ pada $\delta c 115.2$ dan $145.7 \mathrm{ppm}$, tiga sinyal karbon metin $s p^{2}$ dan tiga sinyal karbon kuartener $s p^{2}$, yang menyimpulkan bahwa senyawa 3 adalah senyawa turunan asam fenolat.

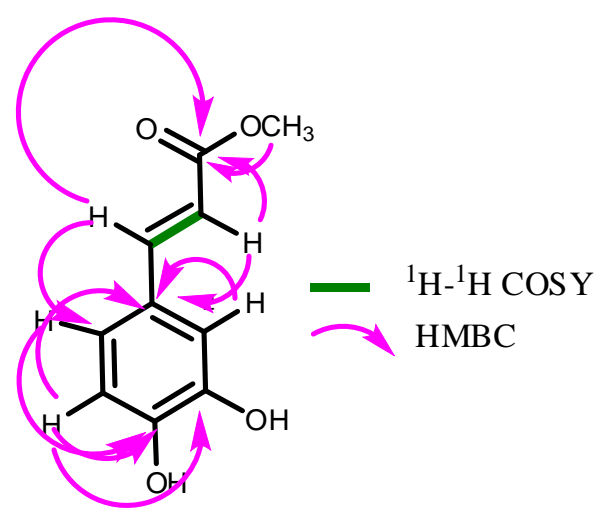

Gambar 3. Korelasi HMBC dan ${ }^{1} \mathrm{H}-{ }^{1} \mathrm{H}$ COSY senyawa 3

Spektrum ${ }^{1} \mathrm{H}-\mathrm{NMR}$, memperlihatkan delapan sinyal proton yang terdiri dari dua sinyal proton pada sistem olefinik, tiga sinyal proton metoksi yang beresonansi pada $\delta_{\mathrm{H}} 3.71$ ppm, dan tiga sinyal proton pada cincin aromatik sistem ABX yang beresonansi pada $\delta_{\mathrm{H}} 6.85$ dan 7.05 ppm berkopling orto $(J=8.4$ $\mathrm{Hz}$ ), sedangkan 7.05 dan 7.15 berkopling meta $(J=1.9 \mathrm{~Hz})$, sehingga pada C-3 dan C-4 terdapat gugus -OH. Data ${ }^{1} \mathrm{H}-{ }^{1} \mathrm{H}$ COSY dan HMBC memperlihatkan korelasi dua ikatan 
$\left({ }^{2} J\right)$ antara sinyal proton-proton (H-7 dan $\left.\mathrm{H}-8\right)$ sebagai olefinik pada senyawa 3 . Dua sinyal proton visinal berkopling trans yang beresonansi pada $6.26\left({ }^{3} J=16.2 \mathrm{~Hz}\right)$ dan 7.51 ppm $\left({ }^{3} J=15.5 \mathrm{~Hz}\right)$. Sinyal proton olefinik dengan $\delta_{\mathrm{H}} 7.51 \mathrm{ppm}(\mathrm{H}-7)$ berkorelasi dengan sinyal karbon $\delta_{\mathrm{C}} 122.6$ (C-6) dan 167.8 ppm (C-9), sedangkan sinyal proton pada $\delta_{\mathrm{H}} 6.26$ ppm (H-8) berkorelasi dengan sinyal karbon $\delta_{\mathrm{C}}$ 127.6 (C-1), dan 167.8 ppm (C-9), mengusulkan bahwa gugus metoksi pada senyawa 3 terletak pada C-9 dan merupakan turunan asam kafeat (Xiang et al., 2011).

Perbandingan data NMR senyawa 3 dengan (E)-metil-(3,4-dihidroksifenil) akrilat (metil kafeat) (Xiang et al., 2011; Kim et al., 2009; Balachandran et al., 2012), menunjukkan kesesuaian yang sangat tinggi, dengan demikian senyawa 3 diidentifikasikan sebagai metil kafeat seperti yang ditunjukkan pada gambar 4 dan tabel 3 .<smiles>COC(=O)/C=C/c1ccc(O)c(O)c1</smiles>

Gambar 4. Metil kafeat (3)

Tabel 3. Data NMR senyawa 3 dan metil kafeat

\begin{tabular}{|c|c|c|c|c|}
\hline \multirow[b]{2}{*}{$\begin{array}{l}\text { Posisi } \\
\text { Atom C }\end{array}$} & \multicolumn{2}{|l|}{ Senyawa $3 *$} & \multicolumn{2}{|l|}{ Metil kafeat** } \\
\hline & $\begin{array}{l}{ }^{1} \mathrm{H}-\mathrm{NMR} \\
\delta_{\mathrm{H}}(\mathrm{ppm}) \\
(\Sigma \mathrm{H} ; \text { mult.; J=Hz) }\end{array}$ & $\begin{array}{l}{ }^{13} \mathrm{C}-\mathrm{NMR} \\
\delta_{\mathrm{C}}(\mathrm{ppm})\end{array}$ & $\begin{array}{l}{ }^{1} \mathrm{H}-\mathrm{NMR} \\
\delta_{\mathrm{H}}(\mathrm{ppm}) \\
(\Sigma \mathrm{H} ; \text { mult.; J=Hz) }\end{array}$ & $\begin{array}{l}{ }^{13} \mathrm{C}-\mathrm{NMR} \\
\delta_{\mathrm{C}}(\mathrm{ppm})\end{array}$ \\
\hline 1 & - & 127.6 & - & 125.5 \\
\hline 2 & $7.15(1 \mathrm{H}, d, 1.9)$ & 116.4 & $7.06(1 \mathrm{H}, d, 2.0)$ & 115.6 \\
\hline 3 & - & 146.3 & - & 145.5 \\
\hline 4 & - & 148.7 & - & 148.4 \\
\hline 5 & $6.85(1 \mathrm{H}, d, 8.4)$ & 115.2 & $6.77(1 \mathrm{H}, d, 8.0)$ & 114.7 \\
\hline 6 & $7.05(1 \mathrm{H}, d d, 1.9 ; 1.9)$ & 122.6 & $7.00(1 \mathrm{H}, d d, 2.0 ; 2.0)$ & 121.4 \\
\hline 7 & $7.51(1 \mathrm{H}, d, 15.5)$ & 145.7 & $7.49(1 \mathrm{H}, d, 16.0)$ & 145.1 \\
\hline 8 & $6.26(1 \mathrm{H}, d, 16.2)$ & 116.4 & $6.27(1 \mathrm{H}, d, 16.0)$ & 115.0 \\
\hline 9 & - & 167.8 & - & 167.0 \\
\hline 10 & $3.71(3 \mathrm{H}, s)$ & 51.5 & $3.69(3 \mathrm{H}, s)$ & 51.2 \\
\hline
\end{tabular}

* Pengukuran dilakukan dengan aseton- $d_{6}$ pada $500 \mathrm{MHz}$ untuk ${ }^{1} \mathrm{H}$ dan $125 \mathrm{MHz}$ untuk ${ }^{13} \mathrm{C}-\mathrm{NMR}$

** Pengukuran dilakukan dalam DMSO- $d_{6}$ pada $400 \mathrm{MHz}$ untuk ${ }^{1} \mathrm{H}$ dan $100 \mathrm{MHz}$ untuk ${ }^{13} \mathrm{C}-\mathrm{NMR}$ (Balachandran et al., 2012)<smiles>O=c1c(O)c(-c2ccc(O)cc2)oc2cc(O)cc(O)c12</smiles>

(1)<smiles>O=c1c(O)c(-c2ccc(O)c(O)c2)oc2cc(O)cc(O)c12</smiles>

(2)<smiles>COC(=O)/C=C/c1ccc(O)c(O)c1</smiles>

(3)

Gambar 5. Struktur senyawa 1-3 dari K. prolifera 
Berdasarkan studi fitokimia pada penelitian ini telah diisolasi tiga metabolit sekunder (1-3) yang terdiri atas senyawa fenolat yaitu kaempferol (1), kuersetin (2), dan metil kafeat (3). Hasil penentuan struktur (1-3) senyawa yang berhasil diisolasi dari $K$. prolifera. adalah seperti yang ditunjukkan oleh tabel 4 dan gambar 5 .

Tabel 4. Senyawa 1-3 dari empat spesies $K$. prolifera

\begin{tabular}{llc}
\hline No & Senyawa & K. prolifera \\
\hline 1 & Kaempferol & $\sqrt{ }$ \\
2 & Kuersetin & $\sqrt{ }$ \\
3 & Metil kafeat & $\sqrt{ }$ \\
\hline
\end{tabular}

\section{SIMPULAN}

Pada daun tanaman $K$. prolifera selain senyawa kuersetin 3-O- $\beta$-L glukopiranosil $(1 \rightarrow 2)-\beta$-D-silopiranosida, telah ditemukan senyawa kaempferol (1), kuersetin (2) dan metil kafeat (3), sebagai metabolit sekunder dari $K$. prolifera.

\section{UCAPAN TERIMA KASIH}

Terima kasih kepada LPPM Unjani yang telah mendanai penelitian ini melalui Hibah Internal Kompetitif Unjani.

\section{DAFTAR PUSTAKA}

Alley MC, Scudiero DA, Monks A, Hursey ML, Czerwinski MJ, Fine DL, Abbott BJ, Mayo JG, Shoemaker RH, Boyd MR. 1988. Feasibility of drug screening with panels of tumor cell lines using a microculturetetrazolium assay. Cancer Research. 48: 589-601.

Anderson LA, Schultz JP, Joubert L, Prozesky TS, Kellerman GL, Erasmus J, Procos. 1983. Krimpsiekte and acute cardiac glycoside poisoning in sheep caused by bufadienolides from the plant Kalanchoe lanceolata Forsk. Onderstepoort J. Vet. Res. 50(4): 295-300.

Awaad AS, Mohamed NH, Maitland DJ, Soliman GA. 2008. Anti-ulcerogenic activity of extract and some isolated flavonoids from Desmotachia bipinnata (L.) stapf. Rec. Nat. Prod. 2(3): 76-82.
Balachandran C, Duraipandiyan V, Al-Dhabi NA, Balakrishna K, Kalia NP, Rajput VS, Khan IA, Ignacimuthu S. 2012. Antimicrobial and antimycobacterial activities of methyl caffeate isolated from Solanum torvum Swartz. Fruit. Indian J. Microbiol. 52(4): 676-681.

Biswas SK, Chowdhury A, Das J, Hosen SMZ, Uddin R, Rahaman MdSh. 2011. Literature review on pharmacological potentials of Kalanchoe pinnata (Crassulaceae). African J. Pharmacy and Pharmacology. 5(10): 1258-1262.

Chaturvedula VSP, Prakash I. 2001. Kaempferol Glycosides from Siraitia grosvenorii. J. Chem. Pharm. Res. 3(6): 799-804.

Costa SS, Muzitano MF, Camargo LMM, Coutinho MAS. 2008. Therapeutic potential of Kalanchoe species: flavonoids and other secondary metabolites. Nat. Pro. Communication. 3(12): 2151-2164.

Dey PM, Harborne JB. 1991. Methods in Plant Biochemistry, Assays for Bioactivity, Vol. 6. Academic Press Limited, San Diego

Edriss AA, Alabjar ZA, Satti AA. 2012. Phytochemical screening of important secondary metabolites in some extracts of two sudanese plants. Glo. Adv. Res. J. Environ. Sci. Toxicol. 1(8): 199-202.

Gaind KN, Gupta RL. 1971. Phenolic components from the leaves of Kalanchoe pinnata, Planta Medica. 23: 149-153.

Gao H, Popescu R, Kopp B, Wang Z. 2011. Bufadienolides and their antitumor activity Nat. Prod. Rep. 28: 953-969.

Harvey AL. 2008. Natural products in drug discovery. Drug Discovery Today. 13(19/20).

Kementrian Kehutanan RI. 2010. Siaran pers Nomor: $\quad S . \quad 251 \quad / P I K-1 / 2010$, Keanekaragaman hayati sektor kehutanan. Retrieved from www.dephut.go.id:http://www.dephut.go.i d/index.php/news/details/7145

Kennedy DO, Wightman EL. 2011. Herbal extracts and phytochemicals: plant secondary metabolites and the enhancement of human brain function. 
American Society for Nutrition. Adv. Nutr. 2: $32-50$.

Kim KD, Song MH, Yum EK, Jeon OS, Ju YW, Chang MS. 2009. 2,4-dihydroxycinnamic esters as skin depigmenting agents. Bull. Korean Chem. Soc. 30(7): 1619-1622.

Kuo PC, Kuo TH, Su CR, Liou MJ, Wu TS. 2008. Cytotoxic principles and $\alpha$-pyrone ring-opening derivatives of bufadienolides from Kalanchoe hybrid. Tetrahedron. 64: 3392-3396.

Liu KCS, Yang SL, Roberts MF, Phillipson JD. 1989. Eupafolin Rhamnosides from Kalanchoe gracillis. Journal of Natural Product. 52(5): 970-974.

Markam KR. 1988. Cara Mengidentifikasi Flavonoid, Terjemahan Kosasih Padmawinata, Penerbit ITB, Bandung

Milad R, El-Ahmady S, Singab AN. 2014. A review of its ethnomedicinal, botanical, chemical, and pharmacological properties. European Journal of Medicinal Plants. 4(1): 86-104.

Son HL, Phuc AN. 2013. Phytochemical composition, in vitro antioxidant and anticancer activities of quercetin from methanol extract of Asparagus cochinchinensis (LOUR.) Merr. Journal of
Medicinal Plants Research. 7(46): 33603366.

Supratman U, Fujita T, Akiyama K, Hayashi H. 2000. New insecticidal bufadienolide, bryophyllin $\mathrm{C}$, from Kalanchoe pinnata. Biosci. Biotechnol. Biochem. 64(6): 13101312.

Wagner H, Fischer M, Lotter H. 1985. Isolation and structure determination of daigremontianin, a novel bufadienolide from Kalanchoe daigremontiana. Planta Med. 51(2): 169-170.

Wu PLH, YL, Wu TS, Bastow KF, Lee KH. 2006. Kalanchosides A-C, new cytotoxic bufadienolides from the aerial parts of Kalanchoe gracilis, Org. Lett. 8(23): 5207-5210.

Xiang M, Su H, Hu J, Yan Y. 2011. Isolation, identification and determination of methyl caffeate, ethyl caffeate and other phenolic compounds from Polygonum amplexicaule var. sinense. Journal of Medicinal Plants Research. 5(9): 1685-1691.

Yamagishi T, Haruna M, Yan XZ, Chang JJ, Lee KH. 1989. Antitumor agents, Bryophyllin B, a novel potent cytotoxic bufadienolide from Bryophyllum pinnatum. Journal of Natural Products. 52(5): 1071-1079. 